\title{
PENGEMBANGAN MULTIMEDIA TUTORIAL MATERI TATA SURYA UNTUK MEMBANTU SISWA BELAJAR DI RUMAH
}

\author{
Yoyong Trye Abdillah, Susilaningsih, Agus Wedi \\ Jurusan Teknologi Pendidikan, Fakultas Ilmu Pendidikan, Universitas Negeri Malang \\ Jalan Semarang 5 Malang 65145 0341-574700 \\ yoyoenks@gmail.com
}

Article History

Received: 9 Agustus 2020, Accepted: 24 November 2020, Published: 26 Februari 2021

\begin{abstract}
Abstrak
Tujuan dari pengembangan ini adalah untuk menghasilkan produk Multimedia Tutorial Materi Tata Surya yang layak pada Mata Pelajaran Ilmu Pengetahuan Alam untuk membantu siswa dalam meningkatkan pemahaman materi secara visual dan meningkatkan hasil belajar siswa. Prosedur pengembangan multimedia pembelajaran interaktif tutorial ini menggunakan model dari Lee \& Owens. Hasil analisis deskriptif dari ahli media menunjukkan bahwa pengembangan multimedia tutorial Tata Surya layak digunakan. Komentar, kritik dan saran ahli media terdapat bahwa media secara umum sudah baik dan istilah pengoperasian materi sebaiknya diubah menjadi penggunaan media. Hasil analisis deskriptif dari ahli materi menunjukkan bahwa pengembangan multimedia tutorial Tata Surya layak digunakan. Komentar, kritik dan saran ahli materi terdapat bahwa keseluruhan materinya sudah sesuai dengan kurikulum SMP dan pengembang diharapkan bisa mengembangkan terus multimedianya yang lebih kreatif, bervariasai dan lebih detail. Hasil tersebut dapat diperoleh bahwa multimedia tutorial layak untuk digunakan pada proses pembelajaran.
\end{abstract}

Keyword: Pengembangan, Multimedia Tutorial,Tata Surya

\begin{abstract}
help the students increasing the comprehension of subject visually and improving student learning result. This multimedia tutorial learning procedure used the model based on Lee \& Owens. The result of the descriptive analysis from media expert shows that multimedia tutorial development of the solar system is worthy to use. The comments, criticisms and advices of media experts are found that media generally good and the term for material operation should be converted into media use. The result of the descriptive analysis of materials suggests that multimedia tutorial development of the solar system is worthy to use. Comments, criticisms and advice from material experts are that the entire material is suitable with a junior high school curriculum and researcher hope to further researcher more creative, varies, and detail. The results can be obtained that multimedia tutorials are worthy to use on the learning process.
\end{abstract}

Keyword: Development, multimedia tutorial, solar system 


\section{PENDAHULUAN}

Penggunaan teknologi kini mempengaruhi perihal kehidupan. Penggunaan tersebut secara langsung dan tidak langsung memiliki dampak perubahan pada aktivitas manusia. Salah satu pengaruh penggunaan IPTEK terhadap aktivitas manusia adalah meningkatnya kualitas pendidikan. Selaras dengan penggunaan tersebut, teknologi kini dapat mempermudah suatu jalannya proses pembelajaran supaya menarik minat siswa, terutama untuk siswa SMP. Salah satu berkembangnya bidang teknologi yang terbaru adalah berkembangnya teknologi multimedia (Nurullah, Soepriyanto, Sulton \& Husna, 2019). Multimedia dapat menjadi solusi untuk mempermudah siswa dalam mempelajari materi dibandingkan dengan buku cetak/e-book yang monoton (Armansyah, Sulton, \& Sulthoni 2019). Multimedia pada umumnya memiliki prinsip yaitu orang belajar lebih baik dari gambar dan kata dari pada hanya sekedar kata-kata saja (Mayer, 2009). Multimedia merupakan alat untuk menciptakan antarmuka presentasi yang interaktif dan dinamis dengan mengkombinasikan antara teks, grafik, animasi, audio, dan video Robbin dan Linda (Ariani, N. \& Haryanto, 2010:11). Penggunaan multimedia dapat menimbulkan interaktivitas dengan penggunannya setelah adanya proses timbal balik dengan media.

Multimedia interaktif memiliki peran dalam penggunaannya salah satunya menggunakan komputer. Dengan adanya komputer, pembelajaran menjadi menarik dimana penggunaan tersebut tidak harus bertatap muka secara langsung dengan guru di kelas melainkan berinteraksi dengan media (Herdiyanto, Sulton \& Praherdhiono, 2020). Multimedia interaktif juga dapat meningkatkan motivasi belajar karena secara individual siswa dapat menguasai materi pelajaran secara utuh, siswa juga dapat mengembangkan kemampuannya secara mandiri dengan multimedia interaktif, keberhasilan belajar dan efisiensi berupa penghematan waktu lebih besar dibandingkan dengan pembelajaran konvensional (Istika, Ngadimun \& Suyanto, 2014).

Model tutorial pada penyajian materinya terdapat panduan pembelajaran yang dilengkapi dengan tutor dan alat pengontrol pada siswa, lalu pengguna dapat menampilkan informasi yang sesuai dengan pengoperasian yang dilakukan oleh pengguna seperti pada keterangan (Hamalik, 2003:73) bahwa tutorial, dapat meningkatkan minat siswa dan aktif dalam kegiatan pembelajaran, meski dilakukan dengan cara mandiri maupun kelompok dan memungkinkan pada siswa untuk memecahkan masalahmasalah belajarnya dengan mandiri, sehingga berdampak pada proses pembelajaran yang terpusat pada siswa. Fungsi multimedia tutorial pada media pembelajaran adalah sebagai tambahan, pelengkap dan pengganti. Dari ketiga fungsi tersebut, saat ini penggunaan multimedia masih dianggap sebagai fungsi tambahan dan pelengkap, dibandingkan fungsi pengganti. Multimedia tutorial memberikan kesempatan bagi siswa untuk belajar dengan mandiri, secara saat ini multimedia dapat dianggap sebagai fungsi pengganti dalam membantu siswa belajar di rumah dengan waktu yang lebih fleksibel. Selaras dengan fungsi tersebut, peran media pembelajaran dapat dimaksimalkan penggunaannya mengingat kebijakan Menteri Kemendikbud saat ini pembelajaran tatap muka ditiadakan dan mengharuskan setiap sekolah malaksanakan pembelajaran daring terhadap siswa, dikarenakan saat ini masih dalam masa pencegahan persebaran covid-19 (Kemendikbud, 2020).

Kemajuan Ilmu Pengetahuan dan Teknologi (IPTEK) diharapkan bisa memberikan dampak positif berkenaan dengan pembelajaran ditandai dengan diperbanyaknya sumber dan media pembelajaran (Praherdhiono, H., \& Adi, 2008:4). Dengan kemajuan IPTEK lembaga pendidikan diharuskan mampu mengembangkan media pembelajaran yang bervariasi, baik secara by design maupun by utilization.

Media adalah bentuk dari segala hal yang dipakai untuk sebuah proses dalam transmisi informasi AECT dalam Basyaruddin (2002). Pemanfaatan media pembelajaran saat ini menggantungkan media buku cetak. Penggunaan media ini sangat klasik atau tradisional dibandingkan penggunaan media digital yang modern, dengan memanfaatkan perkembangan teknologi media pembelajaran dapat dibentuk dengan kreatif dan inovatif. Penggunaan media buku cetak berdampak pada kurangnya motivasi, 
perhatian dan minat belajar siswa karena media buku cetak hanya memberikan kesan biasa bagi siswa. Salah satu penggunaan teknologi saat ini yang secara umum dimiliki oleh peserta didik dan guru adalah PC dan laptop selain itu sekolah sebagai wadah atau tempat berlangsungnya pendidikan berbagai sarana dan prasarana telah ditunjang, yaitu adanya laboratorium komputer dan LCD proyektor. Menurut (Sihkabuden, 2011:1) memanfaatkan media merupakan saran dalam bentuk perantara yang berperan untuk menyebarkan ide seseorang, sehingga gagasan itu sampai pada penerima.

Pembelajaran merupakan suatu sistem yang terdiri atas berbagai komponen secara berinteraksi untuk mencapai tujuan pembelajaran yang telah ditetapkan (Admaja, Kuswandi \& Soepriyanto, 2019). Pembelajaran menggunakan komputer merupakan sebuah pemanfaatan pada komputer untuk mendukung dalam menyampaikan materi pembelajaran kepada siswa, dapat secara langsung melihat kemajuan belajar pada materi pembelajaran dan penyajian materi sesuai yang dibutuhkaan oleh siswa secara mandiri atau bentuk memanfaatkan aplikasi yang sudah tersedia sesuai dengan penggunaan komputer yang digunakan dalam kegiatan pembelajaran secara langsung untuk menyajikan isi materi dan menyediakan latihan soal bagi siswa (Rachmadtullah et al., 2018).

Berdasarkan observasi dan wawancara kepada guru IPA kelas VII di SMPN 1 Pagelaran. Pembelajaran materi Tata Surya yang disajikan oleh guru diajarkan secara konvensional dengan menggunakan metode ceramah. Selain itu pada kondisi pandemi covid-19 siswa diharuskan untuk belajar di rumah dengan batas waktu yang belum ditentukan. Berlangsungnya pembelajaran pada materi Tata Surya yang bersifat pasif karena hanya menggunakan media buku cetak yang menyajikan gambar diam untuk itu diperlukan adanya perubahan pembelajaran yang menuntut siswa secara aktif dengan memanfaatkan multimedia tutorial yang kreatif dan inovatif sebagai sumber belajar siswa. Dalam proses pembelajaran kurikulum 2013 pembelajaran berpusat kepada siswa artinya siswa diwajibkan berperan aktif dalam kegiatan pembelajaran (Anas, Soepriyanto \& Susilaningsih, 2018). Dari penjelasan yang telah dipaparkan, maka diperlukan adanya perubahan peran pembelajaran antara guru dengan siswa. Sehingga diperlukan media lain untuk mendorong kemauan siswa dan meningkatkan hasil belajar siswa terhadap meteri tersebut. Masalah tersebut diatasi dengan menggunakan multimedia tutorial dalam proses pembelajaran. Berdasarkan hasil diskusi pengembang dengan guru, sangat disesalkan, karena pada sekolah tersebut tersedianya laboratorium komputer dan LCD proyektor yang tidak dimaksimalkan penggunaannya. Padahal, kemampuan untuk memaksimalkan penggunaan teknologi yang disediakan sangatlah besar dan dapat meningkatkan kualitas pendidikan secara signifikan.

Multimedia tutorial materi Tata Surya ini dikembangkan dengan menggunakan software dari Indigo Rose yaitu AutoPlay Media Studio 8. Software AutoPlay Media Studio 8 ini dapat digunakan sebagai alternatif pembuatan media pembelajaran audio dan visual (Hasan \& Hermanto, 2019). Penggunaan software AutoPlay Media Studio 8 sebagai pengembangan multimedia tutorial secara signifikan dapat meningkatkan hasil belajar siswa daripada hasil belajar menggunakan model pembelajaran konvensional (Sulistiyo \& Alfan, 2015). Menurut (Djamarah, Bahri \& Zain, 2010) bahwa media pembelajaran dengan menggunakan unsur suara, gambar, animasi dan video akan jauh lebih baik daripada media pembelajaran konvensional. Ilmu Pengetahuan Alam menurut (Tala \& Vesterinen, 2015; Waldrip et al., 2010) merupakan ilmu yang mempelajari tentang gejala alam beserta kejadian alam sebagaimana fakta, konsep dan hukum, yang keabsahannya terbukti dari berbagai rangkaian penelitian. IPA dilihat dari dua sisi, yaitu IPA sebagai pembelajaran yang menghasilkan suatu produk hasil kerja ilmuwan dan pembelajaran IPA sebagai proses ilmuwan bekerja untuk menghasilkan ilmu pengetahuan.

\section{METODE}

Sesuai dengan tujuan penelitian dan pengembangan yang akan dilakukan adalah menciptakan produk multimedia tutorial yang layak, mudah dioperasikan, mudah dipahami, dan memotivasi siswa untuk belajar secara mandiri. Maka model pengembangan ini menggunakan model Lee \& Owens (2004) dengan tahapan, diantaranya Analisis, Desain, Pengembangan \& Implementasi dan Evaluasi. Alasan 
menerapkan model pada pengembangan ini karena merupakan model pengembangan yang dikhususkan sebagai mengembangkan multimedia tutorial. Terdapat beberapa langkah dan tahap pengembangan yang terdiri dari prosedur yang ditunjukkan pada Gambar 1.

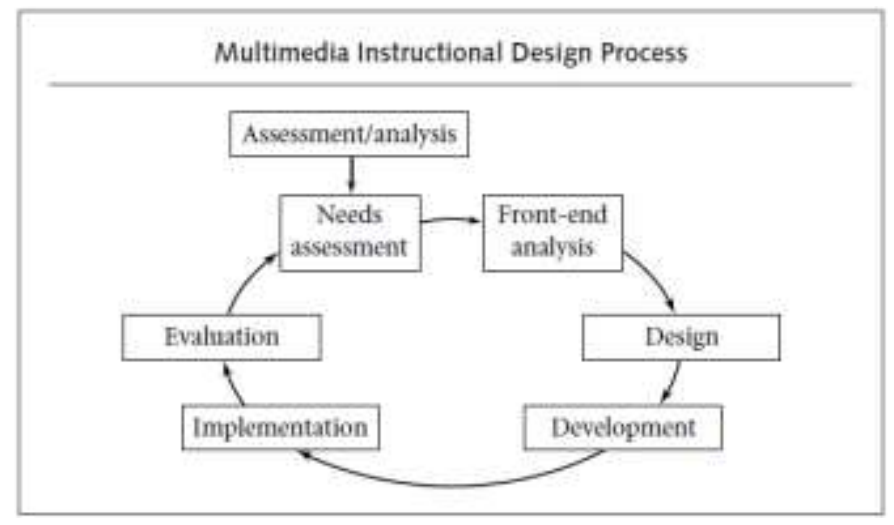

Gambar 1. Prosedur Pengembangan Model Lee \& Owens (2004:3)

Tahap pertama adalah Analisis. Analisis merupakan kegiatan tahap awal yang harus dilakukan sebelum melakukan tahap produksi. Dalam kegiatan tersebut mencakup analisis kebutuhan (Needs assessment) dan analisis awal-akhir (Front-end analysis) (Lee \& Owens, 2004).

Tahap desain merupakan tahap rancangan dan perencanaan dari media/produk yang akan dikembangkan menurut (Lee \& Owens, 2004) adapun tindakan pelaksanaan yang perlu dilakukan pada tahap ini, antara lain jadwal pembuatan, proyek tim, spesifikasi pada media, menyusun struktur konten dan kontrol sistem konfigurasi. Materi yang akan disajikan dalam media yang akan dikembangkan yaitu tentang Ilmu Pengetahuan Alam materi Tata Surya untuk siswa kelas VII Sekolah Menengah Pertama. Kegiatan selanjutnya yaitu merancang produk meliputi pembuatan storyboard.

Tahap pengembangan merupakan kegiatan produksi media dalam hal ini pengembangan multimedia tutorial di kembangkan berdasarkan dari kerangka storyboard yang sudah selesai dibuat. Pengembangan multimedia tutorial dirancang sesuai dengan elemen-elemen storyboard dalam menyusun layout, mendesain interface, merancang button, editing gambar dan membuat animasi. Pelaksanaan pengembangan multimedia tutorial ini terbatas dan tidak melaksanakan pada tahap implementasi dan evaluasi.

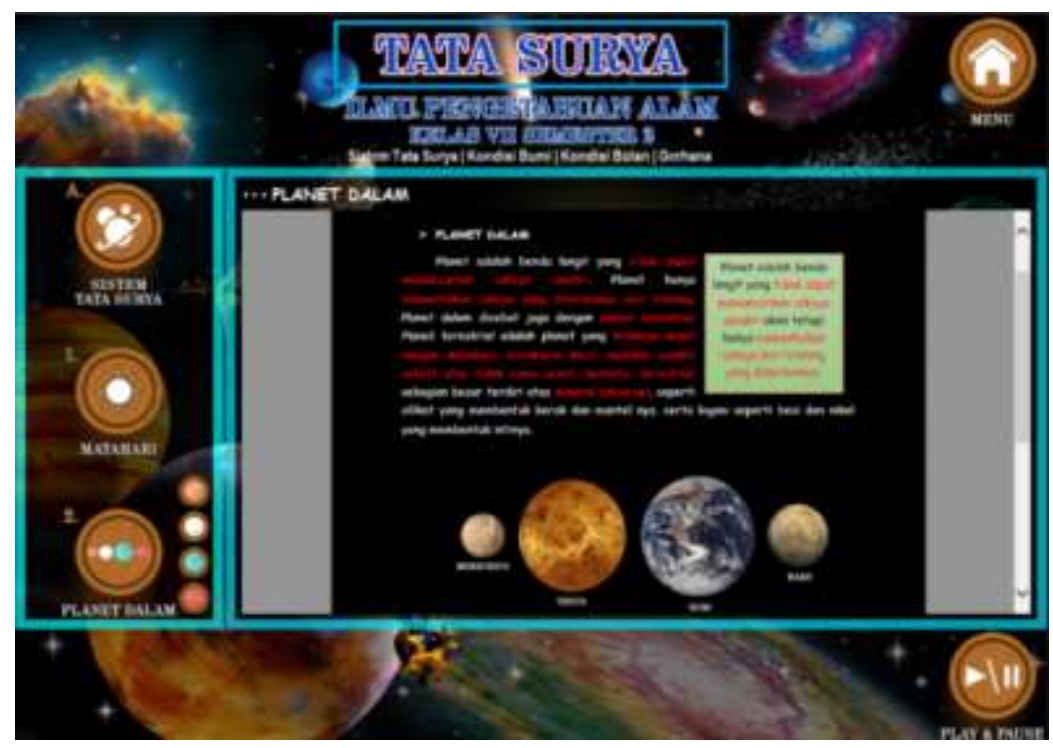

Gambar 2. Tampilan visual produk multimedia tutorial 


\section{HASIL}

Gambar 2 menyajikan tampilan visual interface produk multimedia tutorial. Interface terdiri dari judul, menu, sajian materi dengan tombol-tombol fungsional untuk interaksi pengguna.

Selanjutnya pada tahap ini akan dilakukan penyajian data yang diperoleh dari ahli media dan ahli materi pada hasil pengembangan produk multimedia tutorial. Data uji coba produk diperoleh dari salah satu ahli media pembelajaran, yaitu dosen jurusan Teknologi Pendidikan Universitas Negeri Malang. Data Uji coba produk diperoleh dari salah satu ahli materi yang merupakan guru Ilmu Pengetahuan Alam di SMPN 1 Pagelaran, Kab. Malang.

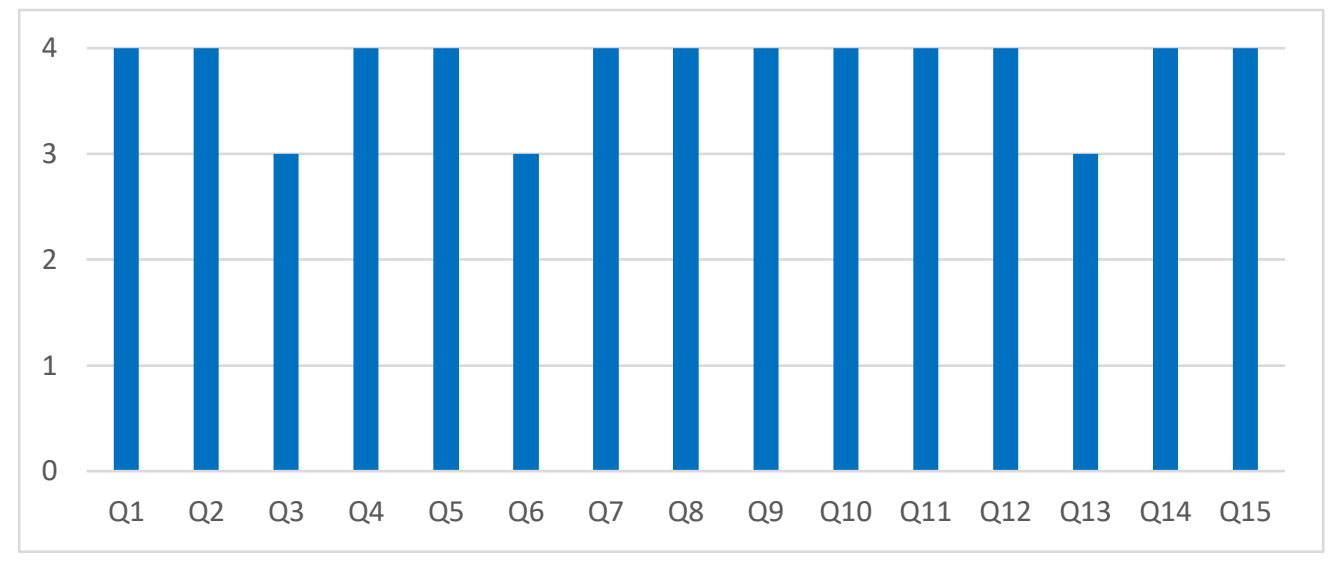

Gambar 3. Grafik tanggapan ahli media

Analisis data deskriptif dari ahli media yaitu Dosen Teknologi Pendidikan mengenai indikator pembelajaran yang terdiri dari 15 aspek pertanyaan yang berhubungan dengan media dan materi pada multimedia tutorial yang dikembangkan. Pada angket respon Ahli Media dalam skala nilai 1-4, ahli media memberikan nilai (4) pada: (Q1) Kesesuaian pemilihan gambar; (Q2) Kesesuaian jenis font; (Q4) Kemenarikan warna dan gambar; (Q5) Kesesuaian latar belakang dan warna font; (Q7) Kemenarikan antarmuka media; (Q8) Kemudahan pengoperasian tombol navigasi; (Q9) Kesesuaian latar belakang musik; (Q10) Kesesuaian efek transisi; (Q11) Kesesuaian animasi; (Q12) Usabilitas/daya guna media; (Q14) Ketepatan kalimat; (Q15) Kejelasan materi. Sedangkan pada aspek lain ahli media memberikan nilai (3) pada: (Q3) Kesesuaian pemilihan ukuran font; (Q6) Tampilan desain variasi; (Q13) Penggunaan bahasa komunikatif. Berdasarkan kriteria yang ditetapkan dapat dijelaskan bahwa pengembangan Multimedia Tutorial Materi Tata Surya Kelas VII Sekolah Menengah Pertama memenuhi kriteria dengan layak diimplementasikan sebagai media pembelajaran.

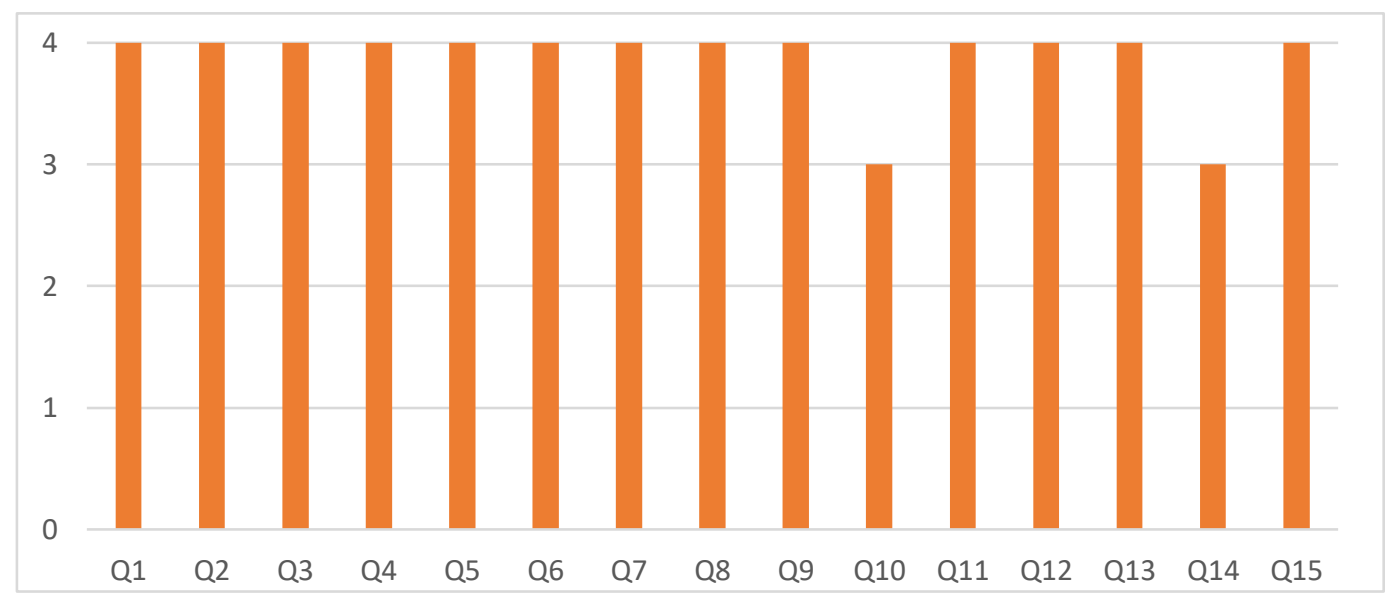

Gambar 4. Grafik tanggapan ahli materi 
Analisis deskriptif dari ahli materi yaitu guru Mata Pelajaran Ilmu Pengetahuan Alam mengenai indikator pembelajaran yang terdiri dari 15 aspek pertanyaan yang berhubungan dengan materi pada multimedia tutorial yang dikembangkan. Pada angket respon Ahli Materi dalam skala nilai 1-4, ahli materi memberikan nilai (4) pada: (Q1) Kesesuaian materi untuk kelas VII; (Q2) Kesesuaian materi dengan karakteristik siswa; (Q3) Kesesuaian materi dengan kurikulum SMP; (Q4) Kesesuaian materi dengan tujuan pembelajaran; (Q5) Kesesuaian materi dengan kompetensi dasar; (Q6) Kesesuaian materi dengan konsep pembelajaran; (Q7) Keruntutan materi; (Q8) Kesesuaian penggunaan animasi dengan materi; (Q9) Kesesuaian penggunaan video dengan materi; (Q11) Kesesuaian materi dengan perkembangan Ilmu Pengetahuan Alam; (Q12) Kesesuaian tingkat bahasa yang digunakan; (Q13) Kesesuaian penggunaan waktu mengerjakan soal; (Q15) Pemanfaatan media menggunakan contoh kasus yang membantu siswa memecahkan masalah kehidupan sehari-hari. Sedangkan pada aspek lain ahli materi memberikan nilai (3) pada: (Q10) Kecukupan proporsi soal latihan; (Q14) Ketertautan media pada ilustrasi dan contoh soal pada buku pelajaran. Berdasarkan kriteria yang ditetapkan dapat dijelaskan bahwa pengembangan Multimedia Tutorial Materi Tata Surya Kelas VII Sekolah Menengah Pertama memenuhi kriteria dengan layak diimplementasikan sebagai media pembelajaran.

\section{PEMBAHASAN}

Analisis Kebutuhan (Needs assessment) merupakan hasil dari wawancara yang dilaksanakan di SMPN 1 Pagelaran dengan salah satu guru Ilmu Pengetahuan Alam bahwa siswa membutuhkan variasi media pembelajaran yang sesuai dengan kebutuhan, yaitu materi Tata Surya. Siswa memerlukan media lain untuk meningkatkan hasil belajarnya, pembelajaran dengan metode ceramah menyebabkan menurunnya hasil belajar siswa, mengingat di SMPN 1 Pagelaran memakai kurikulum 2013. Siswa juga membutuhkan adanya inovasi baru dalam pembelajaran yang mengkaitkan teknologi sebagai perangkat berpikir untuk meningkatkan motivasi belajar siswa dan memaksimalkan adanya ruangan laboratorium komputer sebagai kegiatan pembelajaran.

Analisis Awal dan Akhir (Front-end analysis) merupakan menganalisis data dan informasi yang dikumpulkan untuk menentukan data dan informasi dari keseluruhan data diperoleh. Dalam penelitian ini tahap Front-end analysis ada beberapa kegiatan pelaksanaan, antara lain:

Audience Analysis, dalam tahap ini sasaran pengembang merupakan siswa kelas VII SMPN 1 Pagelaran. Menurut hasil observasi, beberapa siswa kelas VII sudah memiliki perangkat laptop secara individu. Selain itu, adapun rata-rata anak kelas VII sudah mampu mengoperasikan PC/Laptop.

Technology Analysis, dalam tahap ini perangkat pendukung PC/Laptop sudah difasilitasi oleh lembaga sekolah, guru dan siswa dapat mengoperasikan untuk memanfaatkan kegiatan pembelajaran. Teknologi yang dipakai untuk mendistribusikan media yaitu melalui $\mathrm{CD}$ atau bisa menggunakan flashdisk. Untuk proses penggunaan multimedia sudah disediakan buku petunjuk penggunaan.

Situation Analysis, dalam tahap ini situasi kegiatan belajar mengajar di SMPN 1 Pagelaran untuk kelas VII sudah berjalan dengan baik. Lokasi sekolah sangat strategis, ruang laboratorium komputer terletak jauh dari jalan raya sehingga tidak bising dan tidak terganggu suara-suara kendaraan. Selain itu fasilitas penunjang untuk kegiatan penelitian ini sudah baik.

Task Analysis, dalam tahap ini siswa akan mendapatkan file multimedia tutorial yang didistribusikan oleh pengembang, kemudian siswa meng-copy file tersebut kedalam PC/Laptop masingmasing. Sehingga siswa bisa mengakses multimedia tutorial secara individual. Siswa juga diharuskan membaca buku panduan untuk mengoperasikan penggunaan multimedia tutorial.

Critical Incident Analysis, dalam tahap ini merupakan analisis kejadian yang penting dimana media menyediakan animasi dan video berupa materi tata surya. Video disajikan dengan sebaik mungkin dengan tujuan menarik perhatian siswa dalam pembelajaran. Animasi disajikan secara runtut sehingga diharuskan ada dalam media. 
Issue Analysis, dalam tahap ini dari identifikasi pengembang pada saat observasi di SMPN 1 Pagelaran, pengembang tidak menemukan masalah dalam hal mengembangkan multimedia tutorial. Pengembang hanya masih perlu dampingan dari guru mengenai materi supaya tolak ukurnya efektif. Selain itu pengembang membutuhkan koneksi internet untuk meningkatkan kualitas multimedia tutorial.

Objective Analysis, dalam tahap ini tujuan dari pengembangan adalah menghasilkan media pembelajaran yang layak. Tujuan lain untuk tercapainya keberhasilan siswa dalam memahami materi tata surya dengan lebih baik. Serta siswa dapat mengerti bagaimana alur penggunaan media.

Media Analysis, dalam tahap ini jenis media yang digunakan adalah berformat exe (Executable) yang dapat diakses melalui PC/Laptop dan dikemas dalam bentuk CD. Secara keseluruhan isi multimedia tutorial sesuai dengan materi yang diajarkan yaitu tata surya. Dalam media terdapat animasi 2D dan 3D yang terdiri dari berbagai benda-benda langit luar angkasa, serta video penjelasan singkat dari sistem tata surya beserta isinya.

Extant-data Analysis, dalam tahap ini produk multimedia tutorial yang dihasilkan berpusat pada pelajaran IPA dengan materi tata surya. Dimana materi tersebut didapat dari buku Kemendikbud yang sesuai dengan Kurikulum 2013 SMP. Materi tersebut secara rinci dijabarkan pada multimedia tutorial.

Cost Analysis, dalam tahap ini penentuan biaya tidak dijabarkan secara rinci mengenai pengeluaran biaya dalam pengembangan multimedia tutorial tata surya. Biaya pengembangan disesuaikan dengan keperluan saja. Selain itu, penggunaan biaya hanya ada pada nice package media yang dikembangkan.

Selain memaksimalkan penggunaan laboratorium komputer ada alasan mengapa perangkat komputer dipakai sebagai perangkat untuk menjalankan media pembelajaran dalam hal ini multimedia tutorial dengan beberapa faktor diantarannya, komputer dapat menjadi pengganti guru dalam belajar, komputer dapat memotivasi para pebelajar lewat variasi media pembelajaran, komputer dapat saling hubungan interaktif antara dua orang atau lebih. Multimedia tutorial juga merupakan solusi pada terbatasnya media pembelajaran di sekolah sebagai sarana sumber belajar bagi peserta didik (Haryaningtias, Suyatna \& Sesunan, 2013)

Multimedia tutorial merupakan salah satu media yang dapat memecahkan suatu permasalahan dalam pendidikan. Terlebih multimedia tutorial dapat menjadi solusi berupa pemerataan dan perubahan inovasi pendidikan. Adanya pembelajaran multimedia tutorial memiliki dampak yaitu, siswa dapat mencerna suatu bentuk materi dari abstrak menjadi bentuk konkret, serta siswa mampu terlibat aktif pada proses kegiatan pembelajaran, mendapati kejadian langsung dan memahami suatu kejadian dalam media dengan suatu bentuk gambar diam ataupun gambar bergerak (Trinawindu, 2016). Tutorial merupakan langkah-langkah dalam melaksanakan bimbingan pembelajaran yang diterapkan ke dalam bentuk arahan, bantuan, petunjuk dan motivasi untuk meningkatkan kepercayaan diri siswa dalam belajar dalam mencapai hasil dan tujuan yang diinginkan.

Penelitian dan pengembangan harus memperhatikan kriteria pada kualitas Van den Akker dan Nieveen (Rochmad, 2012). Secara kualitas pengembangan multimedia tutorial tersebut dikembangkan dengan sangat baik dari berbagai aspek multimedia. Multimedia tutorial materi Tata Surya yang dikembangkan bisa disebut layak jika dapat meningkatkan hasil belajar siswa dan memotivasi siswa untuk lebih aktif dalam kegiatan pembelajaran (Humienny \& Berta, 2018).

Revisi produk merupakan bentuk evaluasi dari hasil pengembangan multimedia tutorial, kesimpulan dan analisa dari ahli media dan ahli materi akan hasil produk yang sudah divalidasikan merupakan bentuk dari kesempurnaan produk dan peningkatan daya guna untuk kegiatan pembelajaran. Revisi produk meliputi tanggapan/saran dari Ahli Media dan Ahli Materi, Tanggapan/saran dari ahli media yaitu, media secara umum sudah baik dan istilah pengoperasian materi sebaiknya diubah menjadi 
penggunaan media. Memperjelas kata perintah pada media yang sesuai dengan kemampuan siswa Sekolah Menengah Pertama dengan bahasa yang komunikatif dapat mempermudah untuk dipahami oleh siswa dalam proses penggunaan media. Tanggapan/saran dari ahli materi yaitu, multimedia tutorial tersebut bahwa keseluruhan materinya sudah sesuai dengan kurikulum SMP dan pengembang diharapkan bisa mengembangkan terus multimedia interaktifnya yang lebih kreatif, bervariasai dan lebih detail. Hal ini dapat mengembangkan proses belajar siswa ke ranah yang lebih luas.

Secara keseluruhan bahwa penelitian dan pengembangan ini mencapai keberhasilan namun, hal tersebut bergantung pada beberapa faktor, seperti karakteristik siswa, penunjang teknologi dan kompabilitas konten. Kegiatan pembelajaran dengan memanfaatkan multimedia tutorial sudah banyak terbukti dan teruji keberhasilannya. Dari meningkatnya hasil belajar siswa, perubahan sikap dalam belajar, meningkatnya minat serta rasa untuk mendalami pemahaman materi. Keberhasilan penggunaan multimedia tutorial dalam pembelajaran terbukti memberikan dampak positif yang dapat dirasakan oleh siswa saat ini, siswa menganggap pembelajaran tersebut menyenangkan dengan mempelajari dan memahami materi tata surya yang ditampilkan secara visual merupakan pengalaman belajar yang baru. Hal tersebut dapat dibuktikan dan dibenarkan dengan hasil penelitian dan pengembangan yang sudah dilakukan sebelumnya oleh (Anggraeni, Sulton \& Sulthoni, 2019) bahwa hasil belajar siswa pada mata pelajaran Bahasa Indonesia yang memanfaatkan multimedia tutorial jauh lebih baik dari pada hasil dari belajar siswa dengan tidak menggunakan multimedia tutorial hasil tersebut ditunjukkan dengan nilai persentase kelas eksperimen lebih tinggi daripada nilai persentase dari kelas kontrol. Sedangkan hasil penelitian dan pengembangan oleh (Anas, Soepriyanto \& Susilaningsih, 2018) mendapati bahwa penerapan multimedia tutorial membuktikan mampu memaksimalkan penggunaan laboratorium komputer dan memfasilitasi pembelajaran di laboratorium komputer. Multimedia tutorial memberikan pengalaman baru bagi siswa, dimana pembelajaran tersebut lebih interaktif, mandiri, dan lebih variatif. Selain itu penyajian materi pada multimedia tutorial dapat mewadahi berbagai gaya belajar siswa.

Program multimedia tutorial dapat dimanfaatkan sebagai perubahan strategi dalam pembelajaran, strategi tersebut menerapkan setiap siswa harus menggunakan satu komputer atau laptop secara individual, dimana siswa dapat belajar dimanapun dengan bantuan perangkat komputer atau laptop tanpa perlu bimbingan guru. Penelitian dan pengembangan lain yang juga dilakukan oleh (Arifin, Setyosari dan Ulfa, 2018) bahwa desain pada multimedia interaktif ini inovatif termuat berbagai materi, alat, simulasi dan kuis. Kegiatan pembelajaran diterapkan pada laboratorium komputer sekolah yang dikemas sesuai dengan karakteristik siswa. Untuk tampilan sangat bervariasi dengan tema alam terbuka. Sedangkan Audio pengembang memasukkan lagu instrument-instrument tertentu pada media. Hal tersebut dapat memberikan pengalaman belajar baru bagi siswa. Hasil penelitian lain yang dilakukan oleh (Armansyah, Sulton \& Sulthoni, 2019) menungkapkan bahwa penggunaan multimedia interaktif telah terbukti efektif meningkatkan minat dan pemahaman materi pada siswa. Meningkatnya pemahaman siswa dengan visualisasi materi pada multimedia interaktif ini bermaksud untuk memperkuat imajinasi siswa. Serta penelitian lain dari (Saifudin, Susilaningsih \& Wedi, 2020) menunjukkan jika hasil belajar siswa pada mata pelajaran IPA dinyatakan berhasil mengalami peningkatan dengan pengembangan multimedia interaktif. Pengembangan multimedia interaktif ini teruji efektivitasnya saat diimplementasikan kepada siswa. Belajar dapat lebih fleksibel dengan adanya multimedia interaktif. Adapun dalam penelitian dan pengembangan dengan jenis multimedia yang sama oleh (Wardani, Setyosari \& Husna, 2019) bahwa temuan multimedia tutorial dengan tema Tata Surya telah terbukti secara nyata keberhasilannya dalam berbagai aspek positif pembelajaran. Penggunaan multimedia tutorial mudah untuk dipahami siswa serta memungkinkannya siswa menguasai diantarannya dalam mencapai tujuan pembelajaran, metode mengajar lebih bervariasi, tidak membuangbuang waktu proses pembelajaran dengan komunikasi verbal melalui penuturan kata-kata oleh guru. Sehingga siswa tidak bosan dan guru tidak kehabisan tenaga. (Rudiawan, Hamidah \& Komaro, 2015). 
Pembelajaran dengan memanfaatkan teknologi multimedia sangat berpengaruh dalam bidang pendidikan hal tersebut dapat meningkatkan ketertarikan dan minat belajar siswa. Pengembangan ini menghasilkan multimedia tutorial yang dioperasikan pada perangkat keras PC atau laptop dimana konten pembelajaran dapat diakses oleh pengguna dan dapat dilakukannya pembelajaran ketika tidak dapat dilakukannya secara langsung dikelas. Fungsi pada pengembangan multimedia tutorial ini masih dianggap sebagai tambahan dan pelengkap sehingga melibatkan siswa untuk aktif sepenuhnya dalam menggunakan dan memanfaatkan materi sesuai dengan keinginannya tanpa harus ada bantuan dari guru. Adapun temuan baru yang dihasilkan dari pengembangan ini adalah penggunaan media mampu memberikan pengalaman yang lebih bagi siswa karena pada saat media digunakan ada dua indera yang berperan secara bersamaan yaitu indera penglihatan dan indera pendengaran, sehingga mampu membantu siswa meningkatkan pemahaman secara audio visual. Perbedaan signifikan dari sisi media pada temuan sebelumnya adalah lebih mendominasinya media pada segi Grafis, Animasi, dan Isi tentunya memberikan pengalaman yang baru pada saat mengakses setiap materinya, selain itu pada seluruh sub-materinya termuat Animasi 2D dan 3D Tata Surya. Berdasarkan pendapat dan analisis deskriptif dari ahli media dan ahli materi telah dibuktikan hasil yang sangat baik yaitu layak untuk diimplementasikan kepada para siswa. Temuan tersebut merupakan bukti bahwa multimedia tutorial dapat memecahkan masalah-masalah pembelajaran yang ada saat ini.

\section{DAFTAR RUJUKAN}

Admaja, A., Kuswandi, D., \& Soepriyanto, Y. (2019). Pengembangan Multimedia Tutorial Untuk Guru Dalam Mengembangkan Software Tes Berbasis Komputer. JINOTEP (Jurnal Inovasi Dan Teknologi Pembelajaran) Kajian Dan Riset Dalam Teknologi Pembelajaran. https://doi.org/10.17977/um031v5i22019p063

Anggraeni, R., Sulton, S., \& Sulthoni, S. (2019). Pengaruh Multimedia Tutorial Terhadap Hasil Belajar Bahasa Indonesia. Jurnal Kajian Teknologi Pendidikan. https://doi.org/10.17977/um038v2i22019p096

Arifin, Y., Setyosari, P., \& Ulfa, S. (2018). Pengembangan Multimedia Interaktik Materi Sandi Morse dalam Kegiatan Ekstrakurikuler Kepramukaan bagi Siswa Kelas V. JKTP.

Armansyah., Sulton., \& Sulthoni. (2019). Multimedia Interaktif Sebagai Media Visualisasi Dasar-Dasar Animasi. Jurnal Kajian Teknologi Pendidikan. https://doi.org/10.17977/um038v2i32019p224

Djamarah, S. Bahri \& Zain, A. (2010). Strategi belajar mengajar. Jakarta, Indonesia: Rineka Cipta.

Hamalik. (2003). Proses Belajar Mengajar. Jakarta: PT. Bumi Aksara., 73.

Haryaningtias, D., Suyatna, A., \& Sesunan, F. (2013). Pengembangan Multimedia Interaktif Tutorial Menggunakan Pendekatan Kontekstual. Jurnal Pembelajaran Fisika Universitas Lampung.

Hasan, B., \& Hermanto, D. (2019). Pelatihan Pembuatan Media Pembelajaran Berbasis AutoPlay bagi Kelompok Kerja Guru Kecamatan Geger di Kabupaten Bangkalan. Abdihaz: Jurnal Ilmiah Pengabdian Pada Masyarakat. https://doi.org/10.32663/abdihaz.v1i2.981

Herdiyanto, D., Sulton, S., \& Praherdhiono, H. (2020). Pengembangan Multimedia Pembelajaran Interaktif pada Materi Tema Tanah bagi Siswa Tunagrahita. JKTP: Jurnal Kajian Teknologi Pendidikan. https://doi.org/10.17977/um038v3i12019p088

Humienny \& Berta. (2018). Interactive Multimedia Learning Environment For Geometrical Specification Indication \& Verification Rules. Procedia CIRP, 75, 161-166.

Istika, D., Ngadimun, N., \& Suyanto, E. (2014). Pengembangan Multimedia Tutorial Interaktif Microsoft Office Word. Jurnal Teknologi Informasi Komunikasi Pendidikan.

Lee, W. W., \& Owens, D. L. (2004). Multimedia-Based Instructional Design. In Pfeiffer. https://doi.org/10.1007/s13398-014-0173-7.2

Mayer, R. E. (2009). Multimedia Learning. In Multimedia Learning. https://doi.org/10.1017/cbo9780511811678 
Muchammad Azwar Anas., Soepriyanto Y., Susilaningsih. (2013). Pengembangan Multimedia Tutorial Topologi Jaringan Untuk SMK Kelas X Teknik Komputer Dan Jaringan. JKTP Volume 1, Nomor 4, Desember 2018.

Niken Ariani, D. H. (2010). Pembelajaran Multimedia di Sekolah. In Jakarta: PT. Prestasi Pustakarya (p. 11).

Nurullah, A., Soepriyanto, Y., Sulton, S., \& Husna, A. (2019). Pengembangan Multimedia Pembelajaran Energi dalam Sistem Kehidupan. JKTP: Jurnal Kajian Teknologi Pendidikan. https://doi.org/10.17977/um038v2i42019p315

Praherdhiono, H., \& Adi, E. P. (2008). Panduan Praktikum Multimedia. Malang: Fakultas Ilmu Pendidikan. Universitas Negeri Malang, 4.

Kemendikbud. (2020). Surat Edaran Mendikbud No 4 Tahun 2020 Tentang Pelaksanaan Kebijakan Pendidikan Dalam Masa Darurat Penyebaran Corona Virus Disease (Covid- 19) - Pusdiklat Pegawai Kementerian Pendidikan dan Kebudayaan. https://Pusdiklat.Kemdikbud.Go.Id/.

Rachmadtullah, R., Zulela, M. S., \& Sumantri, M. S. (2018). Development Of Computer-Based Interactive Multimedia: Study On Learning In Elementary Education. International Journal of Engineering and Technology (UAE). https://doi.org/10.14419/ijet.v7i4.16384

Rochmad. (2012). Desain Model Pengembangan Perangkat Pembelajaran. Jurnal Kreano, 3(1), 14.

Rudiawan, D., Hamidah, I., \& Komaro, M. (2015). Pengaruh Multimedia Model Tutorial Terhadap Hasil Belajar Gambar 3 Dimensi Siswa SMK. Journal of Mechanical Engineering Education. https://doi.org/10.17509/jmee.v2i1.1150

Saifudin, M., Susilaningsih, S., \& Wedi, A. (2020). Pengembangan Multimedia Interaktif Materi Sumber Energi untuk Memudahkan Belajar Siswa SD. JKTP: Jurnal Kajian Teknologi Pendidikan. https://doi.org/10.17977/um038v3i12019p068

Sihkabuden. (2011). Media Pembelajaran. In Malang: Departemen Pendidikan Nasional Universitas Negeri Malang Fakultas Ilmu Pendidikan. (p. 1).

Sulistiyo, E., \& Alfan, M. (2015). Perbandingan Media Pembelajaran (AutoPlay Media Studio) Sebagai Alat Bantu Pembelajaran Memperbaiki CD Player Siswa Kelas XI di SMK Negeri 3 Surabaya. Jurnal Pendidikan Teknik Elektro.

Tala, S., \& Vesterinen, V. M. (2015). Nature of Science Contextualized: Studying Nature of Science with Scientists. Science and Education. https://doi.org/10.1007/s11191-014-9738-2

Trinawindu. (2016). Multimedia Interaktif untuk Proses Pembelajaran. Multimedia Interaktif Untuk Proses Pembelajaran. Jurnal Prabangkara., 19(23), 35-42.

Waldrip, B., Prain, V., \& Carolan, J. (2010). Using Multi-Modal Representations To Improve Learning In Junior Secondary Science. Research in Science Education. https://doi.org/10.1007/s11165-0099157-6

Wardani, S. K., Setyosari, P., \& Husna, A. (2019). Pengembangan Multimedia Tutorial Mata Pelajaran IPA Pokok Bahasan Sistem Tata Surya Kelas VII MTS Raudlatul Ulum. Jurnal Kajian Teknologi Pendidikan, 2(1), 23-29. 